Institute of $\mathbf{F}_{\text {ood and }} \mathbf{A}$ gricultural $\mathbf{S}_{\text {ciences }}$

\title{
Melon Thrips, Thrips palmi Karny (Thysanoptera: Thripidae) ${ }^{1}$
}

J. L. Capinera ${ }^{2}$

\section{Distribution}

In recent years melon thrips has spread from Southeast Asia to most of the rest of Asia, and to many Pacific Ocean islands, North Africa, Australia, Central and South America, and the Caribbean. In the United States it was first observed in Hawaii in 1982, Puerto Rico in 1986, and Florida in 1990. It has the potential to infest greenhouse crops widely, but under field conditions its distribution likely will be limited to tropical areas. In Florida, so far it is a field pest only south of Orlando.

\section{Life Cycle and Description}

A complete generation may be completed in about 20 days at $30^{\circ} \mathrm{C}$, but it is lengthened to 80 days when the insects are cultured at $15^{\circ} \mathrm{C}$. Melon thrips are able to multiply during any season that crops are cultivated but are favored by warm weather. When crops mature, their suitability for thrips declines, so thrips growth rate diminishes even in the presence of warm weather. In southern Florida they are damaging on both autumn and spring vegetable crops (Seal and Baranowski 1992, Frantz et al. 1995).
In Hawaii, they also become numerous on vegetables during the summer growing season (Johnson 1986).

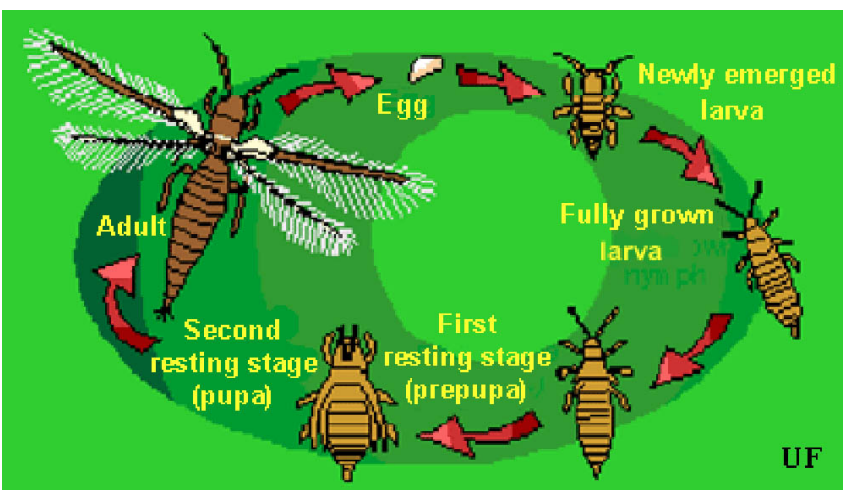

Figure 1. Thrips life cycle. Credits: Jane C. Medley, University of Florida

\section{Eggs}

Eggs are deposited in leaf tissue, in a slit cut by the female. One end of the egg protrudes slightly. The egg is colorless to pale white in color, and bean-shaped in form. Duration of the egg stage is about 16 days at $15^{\circ} \mathrm{C}, 7.5$ days at $26^{\circ} \mathrm{C}$, and 4.3 days at $32^{\circ} \mathrm{C}$.

1. This document is EENY-135, one of a series of Featured Creatures from the Entomology and Nematology Department, Florida Cooperative Extension Service, Institute of Food and Agricultural Sciences, University of Florida. Published: June 2000. This document is also available on Featured Creatures Website at http://creatures.ifas.ufl.edu. Please visit the EDIS Website at http://edis.ifas.ufl.edu. Additional information on these organisms, including many color photographs, is available at the Entomology and Nematology Department website at http://entnemdept.ifas.ufl.edu/.

2. J. L. Capinera, professor/chairman, Entomology and Nematology Department, Cooperative Extension Service, Institute of Food and Agricultural Sciences, University of Florida, Gainesville, FL 32611.

The Institute of Food and Agricultural Sciences is an equal opportunity/affirmative action employer authorized to provide research, educational information and other services only to individuals and institutions that function without regard to race, color, sex, age, handicap, or national origin. For information on obtaining other extension publications, contact your county Cooperative Extension Service office. Florida Cooperative Extension Service/Institute of Food and Agricultural Sciences/University of Florida/Christine Taylor Waddill, Dean. 


\section{Larvae}

The larvae resemble the adults in general body form though they lack wings and are smaller. There are two instars during the larval period. Larvae feed in groups, particularly along the leaf midrib and veins, and usually on older leaves. Larval development time is determined principally by the suitability of temperature, but host plant quality also has an influence. Larvae require about 14,5 , and 4 days to complete their development at 15,26 , and $32^{\circ} \mathrm{C}$, respectively. At the completion of the larval instars the insect usually descends to the soil or leaf litter where it constructs a small earthen chamber for a pupation site.

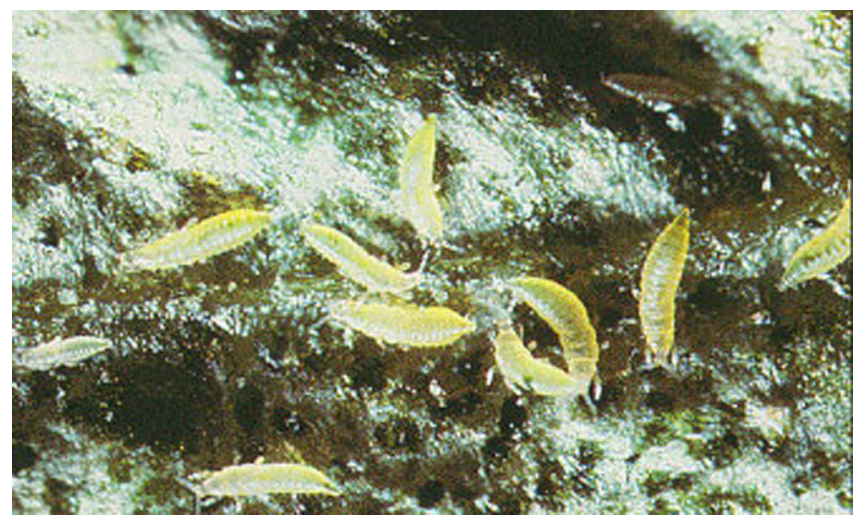

Figure 2. Larvae of the melon thrips, Thrips palmi Karny. Credits: Division of Plant Industry

\section{Pupa}

There are two instars during the "pupal" period. The prepupal instar is nearly inactive and pupal instar is inactive. Both instars are nonfeeding stages. The prepupae and pupae resemble the adults and larvae in form, except that they possess wing pads. The wing pads of the pupae are longer than that of the prepupae. The combined prepupal and pupal development time is about 12,4 , and 3 days at 15, 26, and $32^{\circ} \mathrm{C}$, respectively.

\section{Adult}

Adults are pale yellow or whitish in color, but with numerous dark setae on the body. A black line, resulting from the juncture of the wings, runs along the back of the body. The slender fringed wings are pale. The hairs or fringe on the anterior edge of the wing are considerably shorter that those on the posterior edge. They measure $0.8-1.0 \mathrm{~mm}$ in body length, with females averaging slightly larger than males. Unlike the larval stage, the adults tend to feed on young growth, and so are found on new leaves. Adult longevity is 10-30 days for females and 7-20 days for males. Development time varies with temperature, with mean values of about 20,17 , and 12 days at 15,26 , and $32^{\circ} \mathrm{C}$. Females produce up to about 200 eggs, but averaging about 50 per female. Both mated and virgin females deposit eggs.

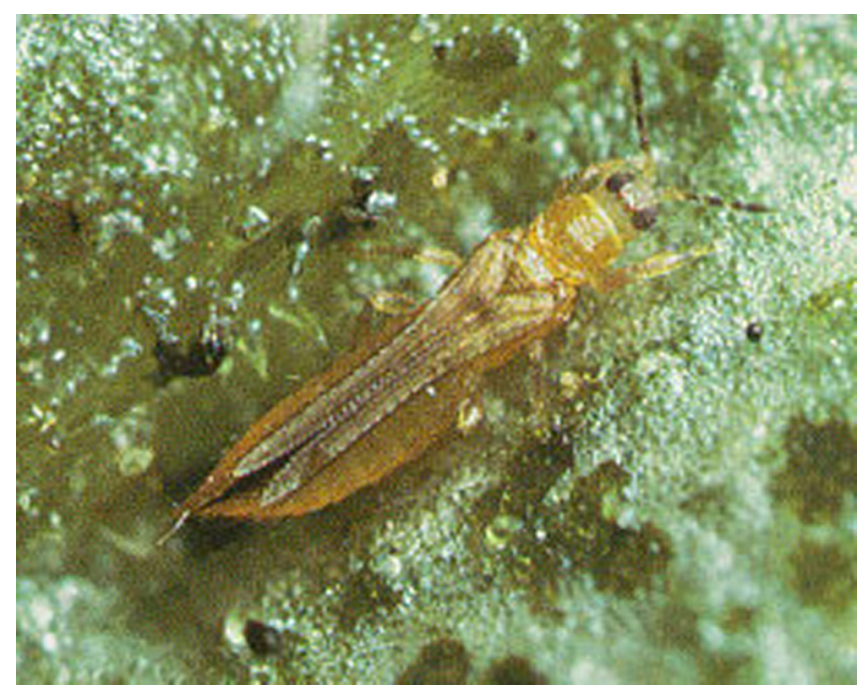

Figure 3. Adult of the melon thrips, Thrips palmi Karny. Credits: Division of Plant Industry

Careful examination is required to distinguish melon thrips from other common species. The Frankliniella species are easily separated because their antennae consist of eight segments, whereas in Thrips species there are seven antennal segments. To distinguish melon thrips from onion thrips, Thrips tabaci Lindeman, it is helpful to examine the ocelli. There are three ocelli on the top of the head, in a triangular formation. A pair of setae are located near this triangular formation, but unlike the arrangement found in onion thrips, the setae do not originate within the triangle. Also, the ocelli bear red pigment in melon thrips whereas they are grayish in onion thrips. In general, the basic body color of adult melon thrips is yellow, but in onion thrips it is yellowish gray to brown.

The most complete summary of melon thrips biology and management is presented in Girling (1992). Developmental biology is given by Tsai et al. (1995). Keys for identification of common thrips are presented by Palmer et al. (1989) and Oetting et al. (1993). 


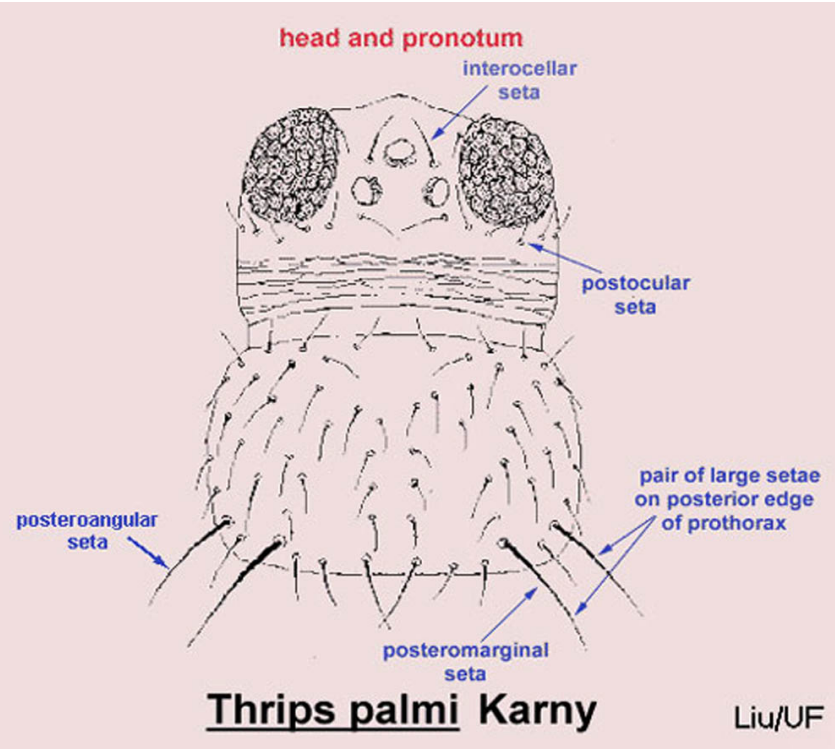

Figure 4. Head and pronotum of the melon thrips, Thrips palmi Karny, with setae identified. Credits: T.X. Liu, Texas A\&M

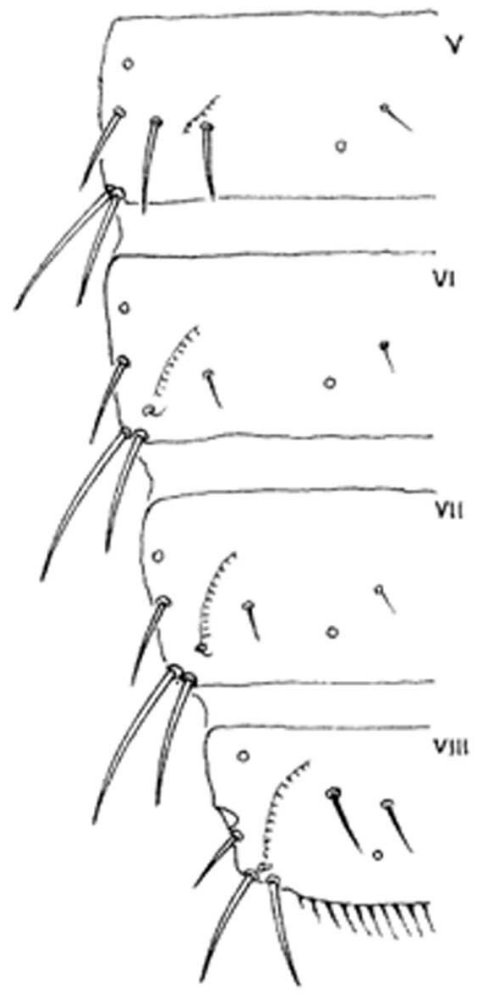

Figure 5. Abdominal segments V-VIII of the melon thrips, Thrips palmi Karny. Credits: K. Sakimura

\section{Host Plants}

Melon thrips is a polyphagous species, but is best known as a pest of Cucurbitaceae and Solanaceae.

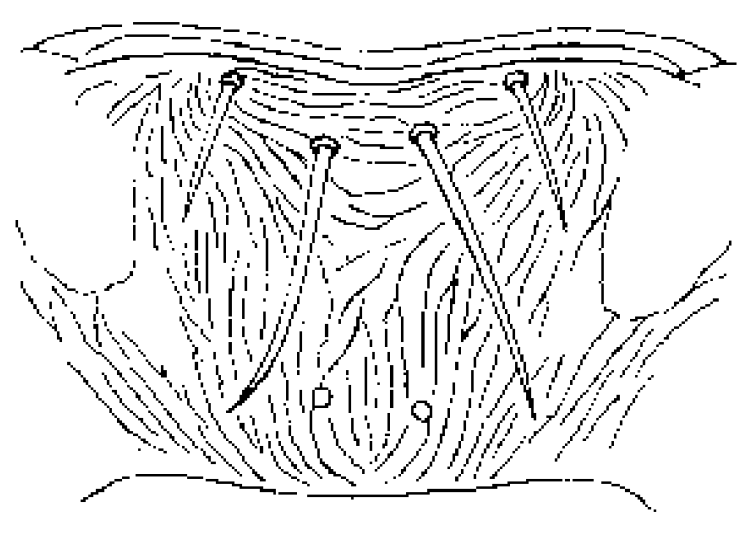

Figure 6. Metascutum (left) and abdominal tergit II (right) of the melon thrips, Thrips palmi Karny. Credits: $\mathrm{K}$.

Sakimura

Among vegetables injured are bean, cabbage, cantaloupe, chili, Chinese cabbage, cowpea, cucumber, eggplant, lettuce, melon, okra, onion, pea, pepper, potato, pumpkin, squash, and watermelon. Tomato is reported to be a host in the Caribbean, but not in the United States or Japan. Tsai et al. (1995) reported that cucurbits were more suitable than eggplant, whereas pepper was less suitable than eggplant. Other crops infested include avocado, carnation, chrysanthemum, citrus, cotton, hibiscus, mango, peach, plum, soybean, tobacco, and others.

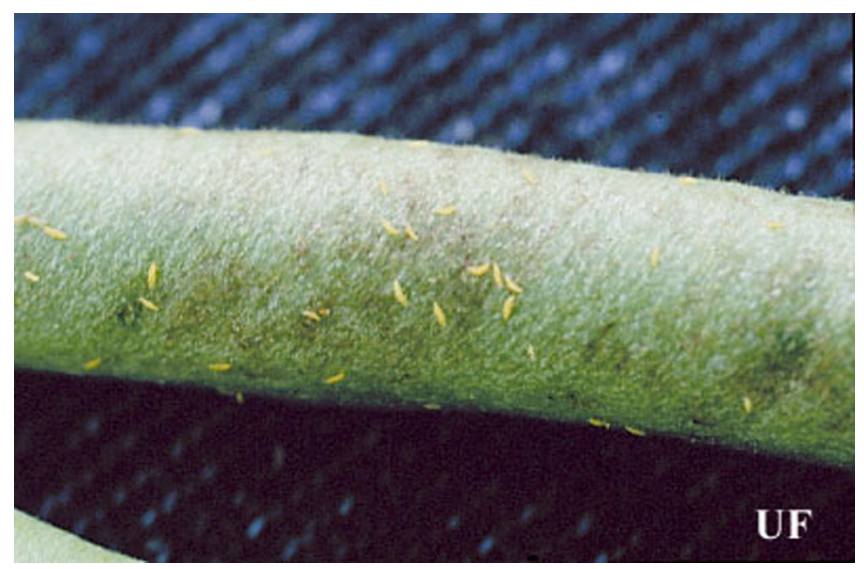

Figure 7. Melon thrips, Thrips palmi Karny, on a bean pod. Credits: University of Florida

\section{Damage}

Melon thrips cause severe injury to infested plants. Leaves become yellow, white or brown, and then crinkle and die. Heavily infested fields sometimes acquire a bronze color. Damaged terminal 
growth may be discolored, stunted, and deformed. Densities from one to 0 per cucumber leaf have been considered to be the threshold for economic damage in some Japanese studies. However, studies in Hawaii suggested a damage threshold of 94 thrips per leaf early in the growth of the plant (Welter et al. 1990). Feeding usually occurs on foliage, but on pepper, a less suitable host, flowers are preferred to foliage. Because melon thrips prefer foliage, they are reported to be less damaging to cucumber fruit than western flower thrips, Frankliniella occidentalis (Pergande) (Rosenheim et al. 1990). Nevertheless, fruits may also be damaged; scars, deformities, and abortion are reported. In Hawaii, thrips were observed to attain higher densities on cucumber plants infected with watermelon mosaic virus, but it was not determined whether the plants were more attractive to adults or suitable for survival and reproduction (Culliney 1990).

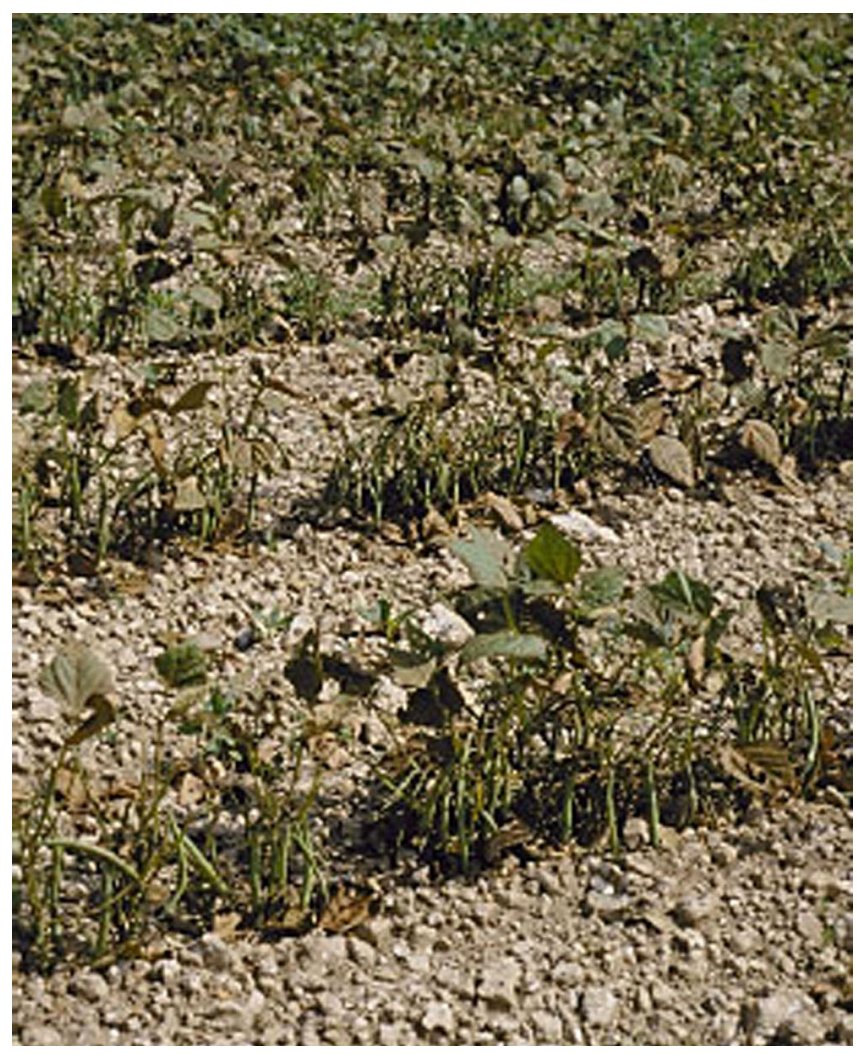

Figure 8. Credits: University of Florida

In addition to direct injury, melon thrips are capable of inflicting indirect injury by transmitting some strains of tomato spotted wilt virus and bud necrosis virus.

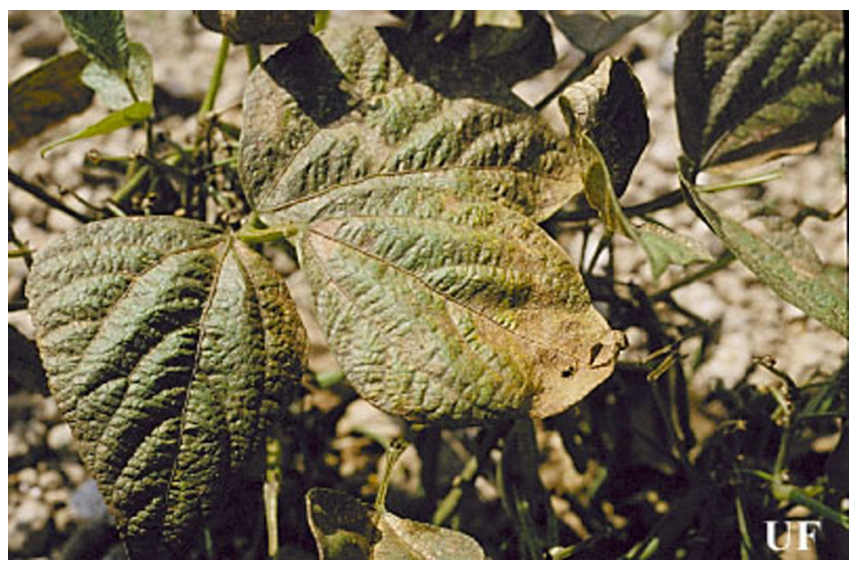

Figure 9. Bean leaf damage caused by the melon thrips, Thrips palmi Karny, showing a close-up of the bronze coloring effect. Credits: University of Florida

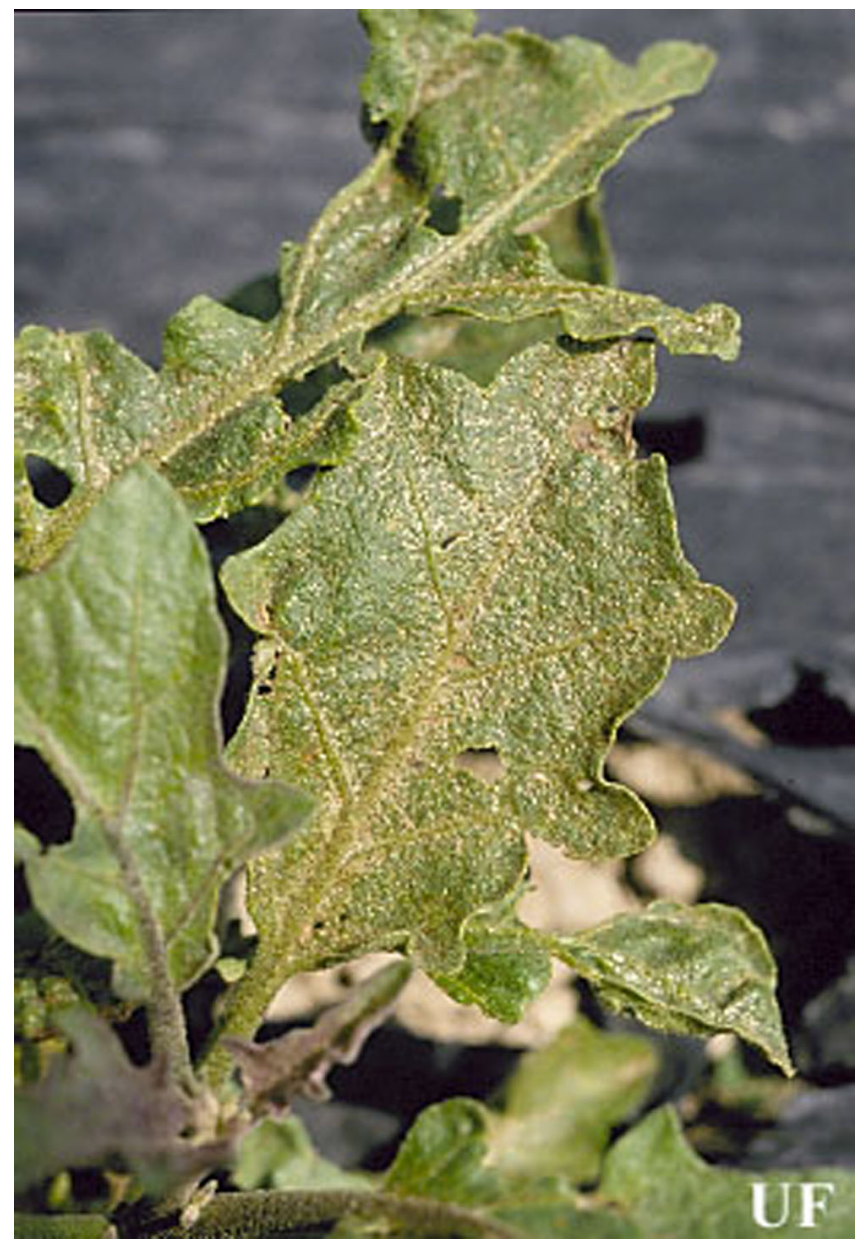

Figure 10. Eggplant leaf damage caused by the melon thrips, Thrips palmi Karny. Credits: University of Florida

\section{Natural Enemies}

Natural enemies, particularly predators, are important in the ecology of melon thrips. In fact, there is strong indication that melon thrips abundance and damage are increased by application of some 


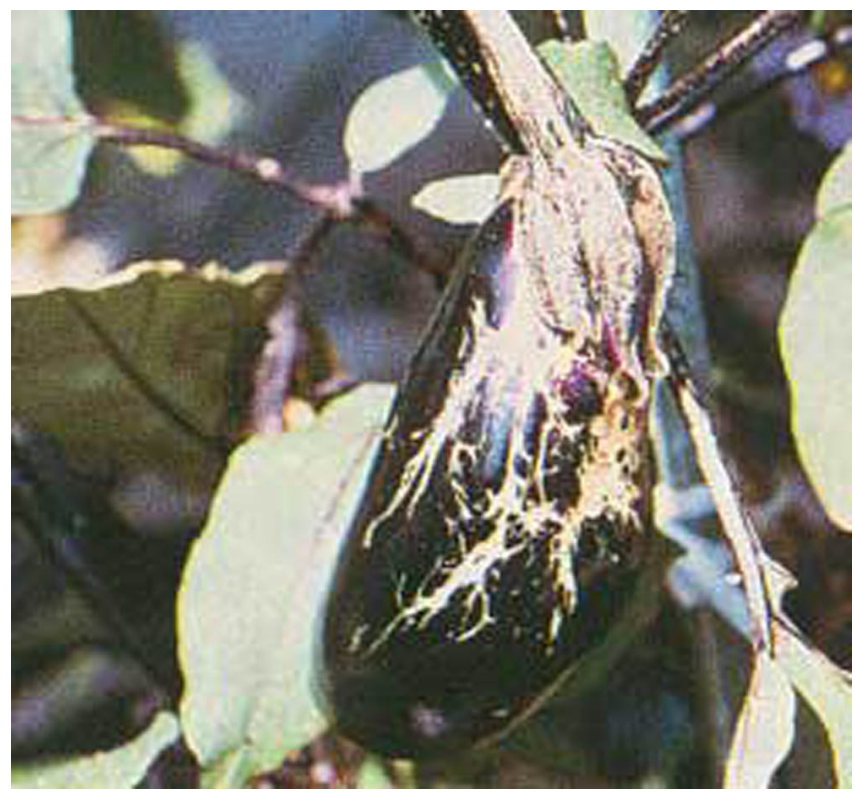

Figure 11. Eggplant scaring damage caused by the melon thrips, Thrips palmi Karny. Credits: Division of Plant Industry

insecticides (Etienne et al. 1990). Among the most important predators observed in Hawaii were the predatory thrips Franklinothrips vespiformis (Crawford) (Thysanoptera: Aeolothripidae) and especially the minute pirate bug Orius insidiosus (Say) (Hemiptera: Anthocoridae). Other predators in Hawaii were the lady beetle Curinus coeruleus (Mulsant) (Coleoptera: Coccinellidae), Rhinacoa forticornis Reuter (Hemiptera: Miridae), and Paratriphleps laevisculus Champion (Hemiptera: Anthocoridae). Other predators and parasitoids are known in Asia (Hirose 1991, Hirose et al. 1993, Kajita 1986). The parasitoid, Ceranisus menes Walker (Hymenoptera: Eulophidae) shows particular benefit in many Asian studies, and this wasp has been introduced to Florida (Castineiras et al. 1996a). Fungi known to affect melon thrips include Beauveria bassiana, Neozygites parvispora, Verticillium lecanii, and Hirsutella sp. (Castineiras et al. 1996b).

\section{Management}

\section{Sampling}

Larvae and adults generally are found on foliage. Adults tend to move toward young foliage, with nymphs tending to be clustered on foliage inhabited by adults several days earlier. Adults can also be sampled with sticky and water pan traps. Blue and white are attractive colors for thrips, and have been

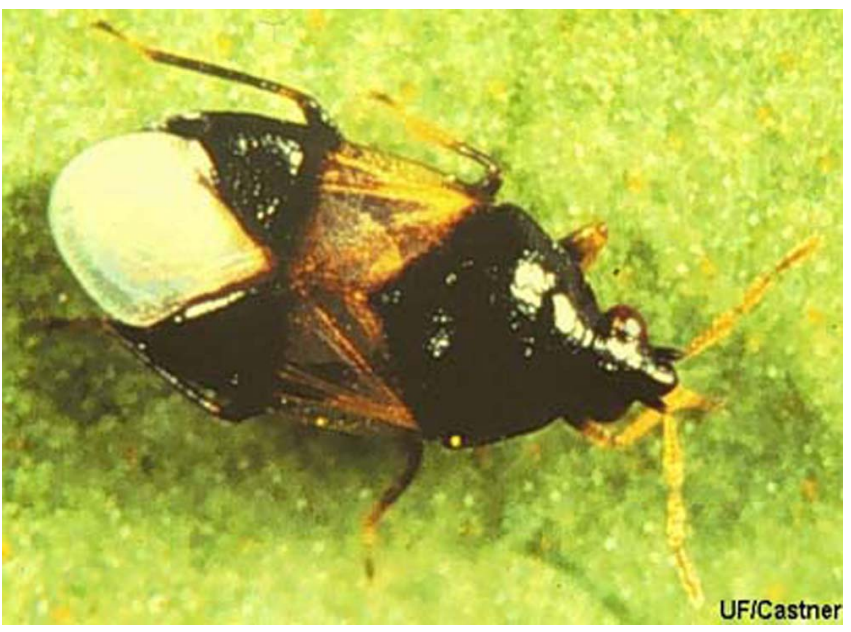

Figure 12. The minute pirate bugs are black with white markings. They prey on many small insects and eggs, including thrips. About 70 species exist in North America. Credits: James Castner, University of Florida

used to trap melon thrips. However, yellow has also been suggested to be an attractive color (Culliney 1990).

\section{Insecticides}

Foliar insecticides are frequently applied for thrips suppression, but at times it has been difficult to attain effective suppression. Various foliar and drench treatments, alone or combined with oil, have achieved some success (Seal and Baranowski 1992, Seal et al. 1993, Seal 1994) though it is usually inadvisable to apply insecticides if predators are present. The eggs, which occur in the foliar tissue, and the pupae, which reside in the soil, are relatively insensitive to insecticide application. For specific recommendations, see:

\section{Insect Management Guide for Vegetables}

\section{Cultural Techniques}

Several cultural practices apparently affect melon thrips abundance, but few have been evaluated in the context of North American agriculture. Physical barriers such as fine mesh and row cover material can be used to restrict entry by thrips into greenhouses, and to reduce the rate of thrips settling on plants in the field.

Organic mulch is thought to interfere with the colonization of crops by winged thrips. Plastic mulch also is reported to limit population growth, but it is 
uncertain whether this is due to reduced rates of invasion or denial of suitable pupation sites. Crop stubble was not an effective deterrent (Litsinger and Ruhendi 1984).

Heavy rainfall is thought to decrease thrips numbers (Etienne et al. 1990). However, there seems to be no evidence that overhead irrigation is an important factor in survival.

\section{Biological Control}

The predatory mite Neoseiulus cucumeris (Oudemans) has been investigated for suppression of melon thrips (Castineiras et al. 1997). The mite density is correlated with thrips density, but within-plant distribution differs among the two species, suggesting that although the mites may increase in numerical abundance they are unlikely to drive the thrips to extinction.

\section{Host Plant Resistance}

Nuessly and Nagata (1995) reported that susceptibility to injury varied among pepper cultivars. They reported that although sweet and jalapeno types were sensitive to foliar injury, cubanelle and cayenne types produced acceptable size and quality fruit. This is the reverse of injury susceptibility to western flower thrips, so in areas with mixed thrips populations growers cannot rely solely on plant selection to avoid damage.

\section{Selected References}

Bhatti, J.S. 1980. Species of the genus Thrips from India (Thysanoptera). Syst. Entomol. 5:109-166.

Capinera, J.L. 2001. Handbook of Vegetable Pests. Academic Press, San Diego. 729pp.

Castineiras, A., R.M. Baranowski, and H. Glenn. 1996a. Temperature response of tow strains of Ceranisus menes (Hymenoptera: Eulophidae) reared on Thrips palmi (Thysanoptera: Thripidae). Florida Entomol. 79:13-19.

Castineiras, A., R.M. Baranowski, and H. Glenn. 1997. Distribution of Neoseiulus cucumeris (Acarina: Phytoseiidae) and its prey, Thrips palmi
(Thysanoptera: Thripidae) within eggplants in south Florida. Florida Entomol. 80:211-217.

Castineiras, A., J.E. Pena, R. Duncan, and L. Osborne. 1996b. Potential of Beauveria bassiana and Paecilomyces fumosoroseus (Deuteromycotina: Hyphomycetes) as biological control agents of Thrips palmi (Thysanoptera: Thripidae). Florida Entomol. 79:458-461.

Culliney, T.W. 1990. Population performance of Thrips palmi (Thysanoptera: Thripidae) on cucumber infected with a mosaic virus. Proc. Hawaiian Entomol. Soc. 30:85-89.

Etienne, J., J. Guyot, and X. van Waetermeulen. 1990. Effect of insecticides, predation, and precipitation on populations of Thrips palmi on aubergine (eggplant) in Guadeloupe. Florida Entomol. 73:339-342.

Frantz, G., F. Parks, and H.C. Mellinger. 1995. Thrips population trends in peppers in southwest Florida. Pages 111-114 in B.L. Parker, M. Skinner, and T. Lewis (eds.). Thrips Biology Management. Plenum Press, New York.

Girling, D.J. (ed.) 1992. Thrips palmi. A Literature Survey with an Annotated Bibliography. International Institute of Biological Control, Silwood Park, Ascot, U.K. 37 pp.

Hirose, Y. 1991. Pest status and biological control of Thrips palmi in southeast Asia. Pages 5760 in N.S. Talekar (ed.). Thrips in Southeast Asia. Asian Veg. Res. and Devt. Ctr., Taipei, Taiwan.

Hirose, Y., H. Kajita, M. Takagi, S. Okajima, B. Napompeth, and S. Buranapanichpan. 1993. Natural enemies of Thrips palmi and their effectiveness in the native habitat, Thailand. Biol. Control 3:1-5.

Johnson, M.W. 1986. Population trends of a newly introduced species, Thrips palmi (Thysanoptera: Thripidae), on commercial watermelon plantings in Hawaii. J. Econ. Entomol. 79:718-720.

Kajita, H. 1986. Predation by Amblyseius spp. (Acarina: Phytoseiidae) and Orius sp. (Hemiptera: 
Anthocoridae) on Thrips palmi Karny (Thysanoptera: Thripidae). Appl. Entomol. Zool. 21:484-484.

Koehler, P.G., D.E.Short and T.R. Fasulo. (1998). Pests In and Around the Home. UF/IFAS. SW-126. CD-ROM.

Litsinger, J.A. and Ruhendi. 1984. Rice stubble and straw mulch suppression of preflowering insect pests of cowpeas sown after puddled rice. Environ. Entomol. 13:500-514.

Nuessly, G.S. and R.T. Nagata. 1995. Pepper varietal response to thrips feeding. Pages 115-118 in B.L. Parker, M. Skinner, and T. Lewis (eds.), Thrips Biology and Management. Plenum Press, New York.

Oetting, R.D., R.J. Beshear, T.-X. Liu, S.K. Braman, and J.R. Baker. 1993. Biology and identification of thrips on greenhouse ornamentals. Georgia Agric. Exp. Stn. Res. Bull. 414. 20 pp.

Rosenheim, J.A., S.C. Welter, M.W. Johnson, R.F.L. Mau, and L.R. Gusukuma-Minuto. 1990. Direct feeding damage on cucumber by mixed-species infestations of Thrips palmi and Frankliniella occidentalis (Thysanoptera: Thripidae). J. Econ. Entomol. 83:1519-1525.

Welter, S.C., J.A. Rosenheim, M.W. Johnson, R.F.L. Mau, and L.R. Gusukuma-Minuto. 1990. Effects of Thrips palmi and western flower thrips (Thysanoptera: Thripidae) on the yield, growth, and carbon allocation pattern in cucumbers. J. Econ. Entomol. 83:2092-2101.

Seal, D.R. 1994. Field studies in controlling melon thrips, Thrips palmi Karny (Thysanoptera: Thripidae) on vegetable crops using insecticides. Proc. Florida State Hort. Soc. 107:159-162.

Seal, D.R., R.M. Baranowski, and J.D. Bishop. 1993. Effectiveness of insecticides in controlling Thrips palmi Karny (Thysanoptera: Thripidae) on different vegetable crops in south Florida. Proc. Florida State Hort. Soc. 106:228-233.

Tsai, J.H., B. Yue, S.E. Webb, J.E. Funderburk, and H.T. Hsu. 1995. Effects of host plant and temperature on growth and reproduction of Thrips palmi (Thysanoptera: Thripidae). Environ. Entomol. 24:1598-1603. 